\title{
Closed-system marine burial diagenesis: isotopic data from the Austin Chalk and its components
}

\author{
LANA ANN CZERNIAKOWSKI*,KYGER C. LOHMANN and JAMES LEE WILSON \\ Department of Geological Sciences, The University of Michigan, Ann Arbor, Michigan, U.S.A.
}

\begin{abstract}
The carbon and oxygen isotopic composition of the Austin Chalk was examined in cores representing a range of depths from surface to $3000 \mathrm{~m}$ in order to document the effects of burial diagenesis on carbon and oxygen isotopic composition. Low magnesium calcite oysters were separated (from $500 \mu \mathrm{m}$ wide areas) and analysed to estimate the starting composition of Cretaceous marine sediment. These gave an average value of $-2 \cdot 5 \%, \delta^{18} \mathrm{O} ;+2 \cdot 0 \% \delta^{13} \mathrm{C}$ (PDB). The compositions of micrite, intergranular cement, and fracture cement were analysed, and their deviation from this original marine composition was evaluated to document the progression of chalk diagenesis. Interestingly, micrite exhibits only minor variation in composition from marine values despite present burial depth ranges in excess of $3000 \mathrm{~m}$. The average deviation from $\delta^{18} \mathrm{O}$ marine is less than $1.5 \%$. Furthermore, intergranular cement and particularly fracture cements, which occur only in the deepest cores and which clearly post-date micrite lithification, are generally indistinguishable from micrite in composition. Isotopic compositions exhibit no correlation with depth of burial despite abundant petrographic evidence of deep burial diagenesis. This uniformity in composition is interpreted as reflecting a closed, rock-dominated diagenetic system in which the compositions of precipitated carbonate cements were controlled by the composition of dissolving carbonates during lithification. As such, the composition of burial cement is not representative of the rock-water temperatures during precipitation.

Thus, in the context of isotopic analyses from other carbonate systems, unless the degree of openness of the diagenetic system is known, oxygen isotopic signatures of cements cannot directly be converted to the rock-water temperatures at which they were precipitated unless the composition of the ambient porefluid is also known.
\end{abstract}

\section{INTRODUCTION}

Chalks have unique mineralogical properties which constrain the pathways of their diagenetic alteration. These deposits consist primarily of low magnesium calcite coccoliths and planktonic foraminifera, with lesser amounts of metastable high magnesium calcite and aragonitic skeletal material. Due to the paucity of metastable mineralogies, chalks are chemically more stable than shallow water carbonates and consequently less susceptible to the extensive dissolution and cementation processes active in such metastable-rich assemblages.

The alteration of chalks largely occurs in diagenetic

*Present address: Conoco Oil Company, North American Exploration, Denver, Colorado, U.S.A. porewaters that were derived from seawater. Initially, this alteration involves a dewatering phase which may reduce depositional porosities by up to $50 \%$ (Schlanger \& Douglas, 1974; Scholle, 1977). As overburden increases, mechanical compaction causes grain breakage and reorientation of primary sedimentary features which in turn reduce intergranular porosity. Later chemical compaction operates by means of pressure solution, resulting in dissolution of carbonate at grain contacts with concomitant local precipitation of the liberated carbonate as cement. This cement precipitates as overgrowths on nannofossils and as crystalline mosaics within intergranular and intragranular pore space (Matter, 1974; Matter, Douglas \& PerchNielsen, 1975). The depth at which pressure solution 
becomes important is not clear, and appears to be a function of the composition of the interstitial fluids (Neugebauer, 1973). Pressure solution is thought to be inhibited as long as the magnesium content of the pore waters remains at a sufficient level to maintain supersaturation with respect to low magnesium calcite, or until a compensation stress is exceeded (Neugebauer, 1974). These considerations suggest that cementation by the products of pressure solution remains insignificant until $300 \mathrm{~m}$ burial. Other estimates of burial depths required for the onset of pressure solution range from 100 to $600 \mathrm{~m}$ (Dunnington, 1967; Beall \& Fischer, 1969).

Essential to the understanding of chalk diagenesis is an improved insight into the processes of shallow versus deep burial diagenesis and how these are expressed, and thereby discriminated, in the final chemical composition of the chalk. Many studies have examined variation in carbon and oxygen isotopic composition to document the progression of diagenesis of chalks in response to burial (Scholle, 1977). It has been generally assumed that recrystallization at greater depth, and likewise at higher diagenetic temperatures, will result in equilibration of carbonate materials with the diagenetic environment; this would be recorded in the diagenetic components by the isotopically light oxygen compositions (Lawrence, 1973; Eade \& Anderson, 1974).

Until recently most of this analytical work has concentrated on whole rock samples in which skeletal and non-skeletal components of chalks have been homogenized. Unfortunately, this approach masks fine-scale differences providing instead an averaged composition of all diagenetic and primary constituents. A clearer understanding of chalk diagenetic histories can be obtained when individual components are microsampled (i.e. bioclasts, micrites, cements) and individually analysed (Dickson \& Coleman, 1980; Hudson, 1977). Therefore, by using an integrated petrographic and geochemical approach to examine the diagenetic evolution of a chalk system at the component level, it may be possible to determine the relationship between burial depth, degree of lithification, and the imparted geochemical signatures.

Ideally, such a study requires a suite of samples of similar starting compositions which have subsequently undergone diagenesis through a range of burial depths. For example, if the depositional carbonate were precipitated from waters of similar temperature and salinites, only minor variation should be present among samples of these prediagenetic carbonates. In contrast, after diagenesis, differences in the porosity, fabric and isotopic composition can be related to the progressive effects of diagenesis with increasing depth of burial.

The Austin Chalk Formation of south-central Texas is ideally suited for such a study. Deposition of the Austin took place in a shelf to basin setting with maximum water depths less than a couple hundred metres. The bulk of the sediment is comprised of coccoliths and planktonic foraminifera both of which would have recorded the temperature and salinity conditions of shallow surface waters. Coarse fragments of an Inoceramus and oyster benthic fauna, which inhabited the adjacent shelf, are common associated skeletal components of the sediment, and their presence likely reflects the periodic transport of shelf-derived material into the basin (Dravis, 1979). In light of their shallow water origins, the isotopic compositions of all faunal components, and in turn of the sediments prior to diagenesis, should have been reasonably constant throughout the area chosen for this study, a trend 160 by $400 \mathrm{~km}$ which parallels the shelf edge (Fig. 1).

Because of the extensive exploration for hydrocarbons in this area, abundant core samples of the Austin Chalk are available. It was possible to construct a sampling traverse, reflecting a range of burial depths

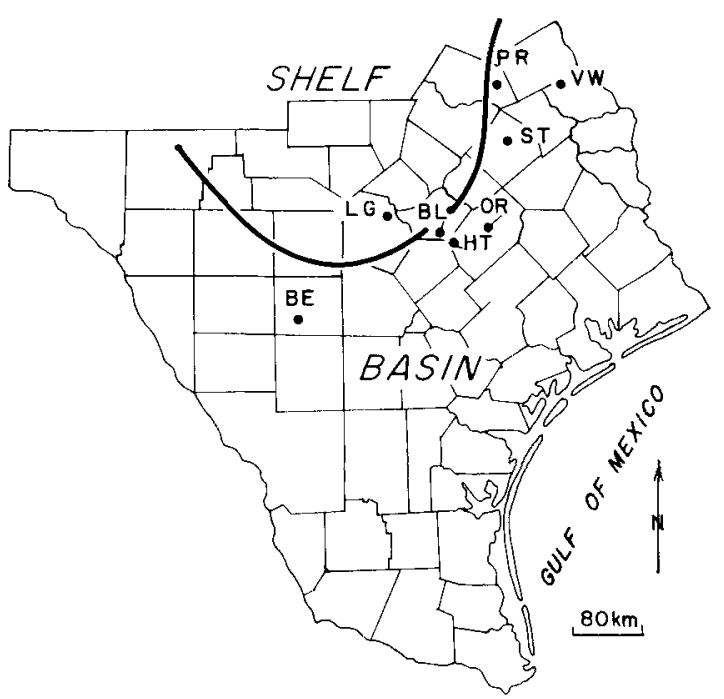

Fig. 1. Location map for Austin Chalk cores in south-central Texas. From these cores a traverse of increasing burial depths was constructed: $\mathrm{LG}^{-}$-Longhorn (outcrop), PRPreuse (340-362 m), ST-Standifer (679-710 m), BL-Blumberg $(966-1001 \mathrm{~m}), \mathrm{HT}$ - Hurts (1356-1391 m), BE-Beall (1712-1822 m), VW--Varner-Wendler (1783-1844 m) and OR-Orts (2195-2369 m). 
from surface outcrops to core depths near $3000 \mathrm{~m}$. Within this context, this study documents the progressive diagenesis of chalk in response to increasing burial and how it is manifested in the geochemical record.

\section{GEOLOGICAL SETTING}

The Austin Chalk ranges in age from Lower Coniacian to Upper Santonian (Dravis, 1979) and was deposited in the shallow epeiric sea which covered the western interior of North America during the late Cretaceous. Palaeobathymetry in the area of this study was influenced by the San Marcos Platform, a structural high which supported a shallow water carbonate shelf with an adjacent basin to the west and NE. Much of these shelf deposits to the NW have since been eroded due to the Miocene uplift along the Balcones Fault zone, with only a narrow outcrop belt of the Austin Formation remaining.

One outcrop and seven core sites were chosen to represent a transect from shallow shelf (outcrop) to deeper basin settings (Fig. 1). Estimates of sediment overburden suggest that the present depths of the Longhorn outcrop and the deeper cores from wells (Blumberg, Hurts, Varner-Wendler, Beall, and Orts) reflect maximum burial depths. On the other hand, it is possible that the Preuse and Standifer cores may have experienced an additional $300-600 \mathrm{~m}$ of Tertiary overburden (Murray, 1961; Young, 1963). The transect from the shelf to basin (with present burial depths in metres) consists of the following localities. Longhorn (outcrop), Preuse (340-362 m), Standifer (679$710 \mathrm{~m})$, Blumberg $(966-1001 \mathrm{~m})$, Hurts (1256$1391 \mathrm{~m})$, Beall $(1712-1822 \mathrm{~m})$, Varner-Wendler (1783-1844 m), and Orts (2195-2369 m). Such a traverse provides a setting of increasing overburden, and presumably increasing temperatures, relative to which progressive diagenesis may be evaluated. In most instances, maximum temperatures occur at maximum burial depths and may be related to the geothermal heat flux of the region. However, due to the emplacement of serpentine plugs during the late Cretaceous, abnormal heat fluxes are probable for some areas. In fact, serpentine occurs at the base of the Austin Chalk section in the Preuse well.

\section{METHODS AND RESULTS}

\section{Petrography}

Polished thin sections and chips were prepared and examined with a standard petrographic microscope. The chalks are light to dark grey packstones to wackestones, the latter being more abundant in the deeper intervals. The matrix consists predominantly of coccoliths and microgranular carbonate grains of indiscernable origin. Other lesser contributors of fine grained skeletal carbonate are calcispheres, and both planktonic and benthic foraminifera. Coarser bioclasts dominantly consist of the prismatic calcite layer of Inoceramus and calcitic oysters (e.g. Exogyra). Minor amounts of echinoderm material are also present. Locally, zones of bored, phosphatic lithoclasts occur with associated glauconite.

The results of standard porosity analyses of these cores have been reported by Dravis (1979), and samples utilized in this study are derived from the same cores. In general, porosity decreases with depth, means ranging from $19 \cdot 3 \%$ for the Longhorn outcrop to $4.1 \%$ for the Orts core (Table 1 ).

Compaction features are common in all subsurface samples, becoming more abundant with increasing burial depth. Mechanical compaction is evidenced by grain breakage and interpenetration, and chemical compaction occurs by pressure solution (Fig. 2).

Table 1. Mean porosity versus mean micrite $\delta^{18} \mathrm{O}_{\mathrm{PDB}}$

\begin{tabular}{|c|c|c|c|c|c|c|}
\hline \multirow[t]{2}{*}{ Sample location } & \multirow{2}{*}{$\begin{array}{l}\text { Stratigraphic } \\
\text { interval } \\
\text { (m) }\end{array}$} & \multirow{2}{*}{$\begin{array}{c}\text { Range } \\
\text { porosity } \\
(\%)\end{array}$} & \multirow{2}{*}{$\begin{array}{c}\text { Mean } \\
\text { porosity } \\
(\%)\end{array}$} & \multicolumn{2}{|c|}{ Mean micrite } & \multirow[t]{2}{*}{ No. } \\
\hline & & & & No. & $\begin{array}{c}\delta^{18} \mathrm{O}_{\mathrm{PDB}} \\
(\%)\end{array}$ & \\
\hline Longhorn & Outcrop & $13 \cdot 7-28 \cdot 4$ & $19 \cdot 3$ & 6 & -3.68 & 21 \\
\hline Preuse & $340-362$ & $11 \cdot 9-22 \cdot 4$ & $16 \cdot 4$ & 8 & $-3 \cdot 21$ & 19 \\
\hline Standifer & $697-710$ & $9 \cdot 5-11 \cdot 3$ & $10 \cdot 4$ & 2 & $-3 \cdot 21$ & 19 \\
\hline Blumberg & $966-1001$ & $3 \cdot 3-12 \cdot 1$ & $5 \cdot 8$ & 36 & -3.59 & 26 \\
\hline Hurts & $1356-1391$ & $6 \cdot 8-15 \cdot 1$ & $10 \cdot 0$ & 10 & $-3 \cdot 40$ & 20 \\
\hline Beall & $1712-1822$ & $1 \cdot 5-9 \cdot 6$ & $4 \cdot 5$ & 226 & $-4 \cdot 13$ & 9 \\
\hline Varner-Wendler & $1783-1844$ & $1 \cdot 0-15 \cdot 1$ & $8 \cdot 1$ & 89 & $-5 \cdot 40$ & 23 \\
\hline Orts & $2195-2369$ & $2 \cdot 1-6 \cdot 1$ & $4 \cdot 1$ & 196 & $-4 \cdot 07$ & 17 \\
\hline
\end{tabular}



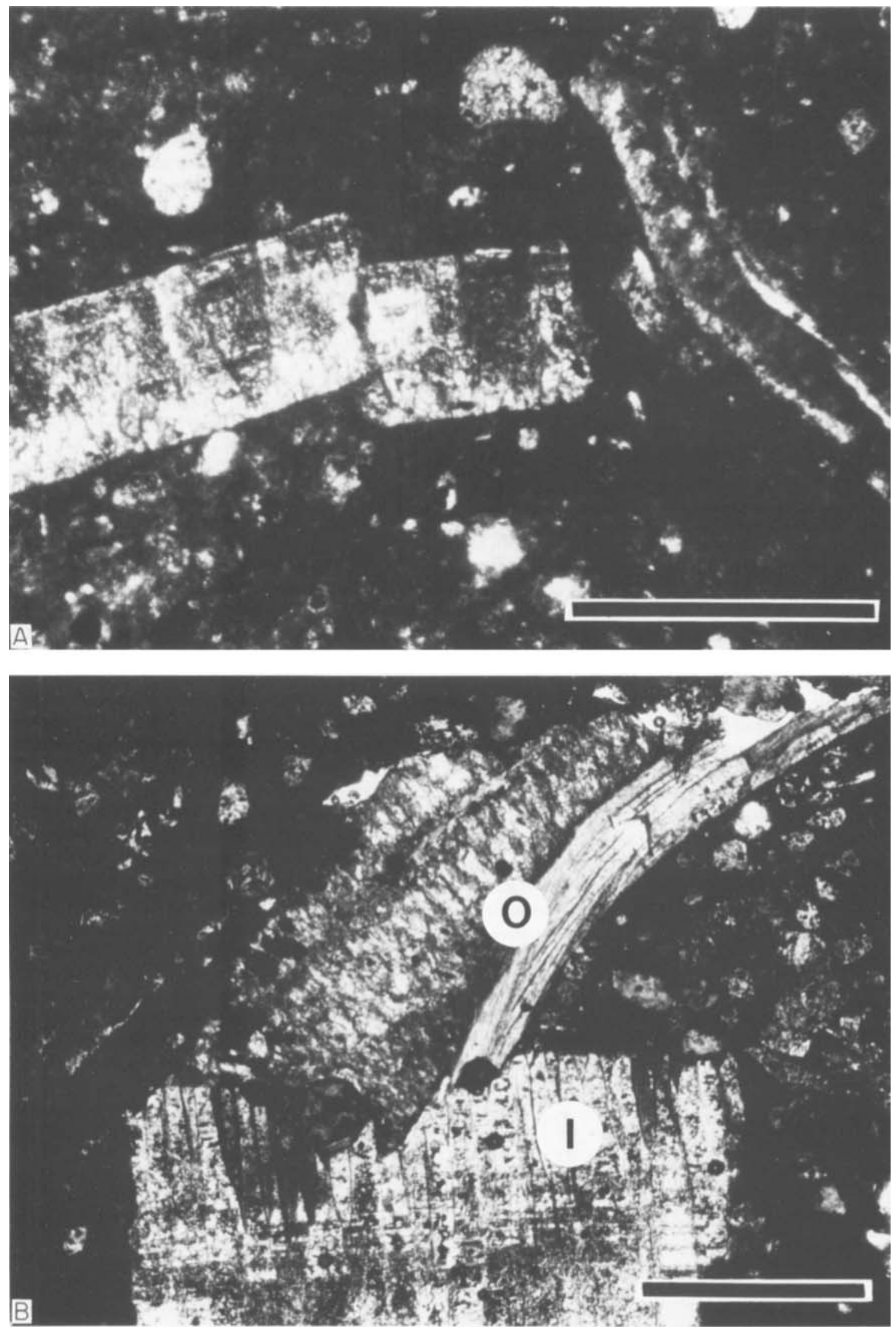


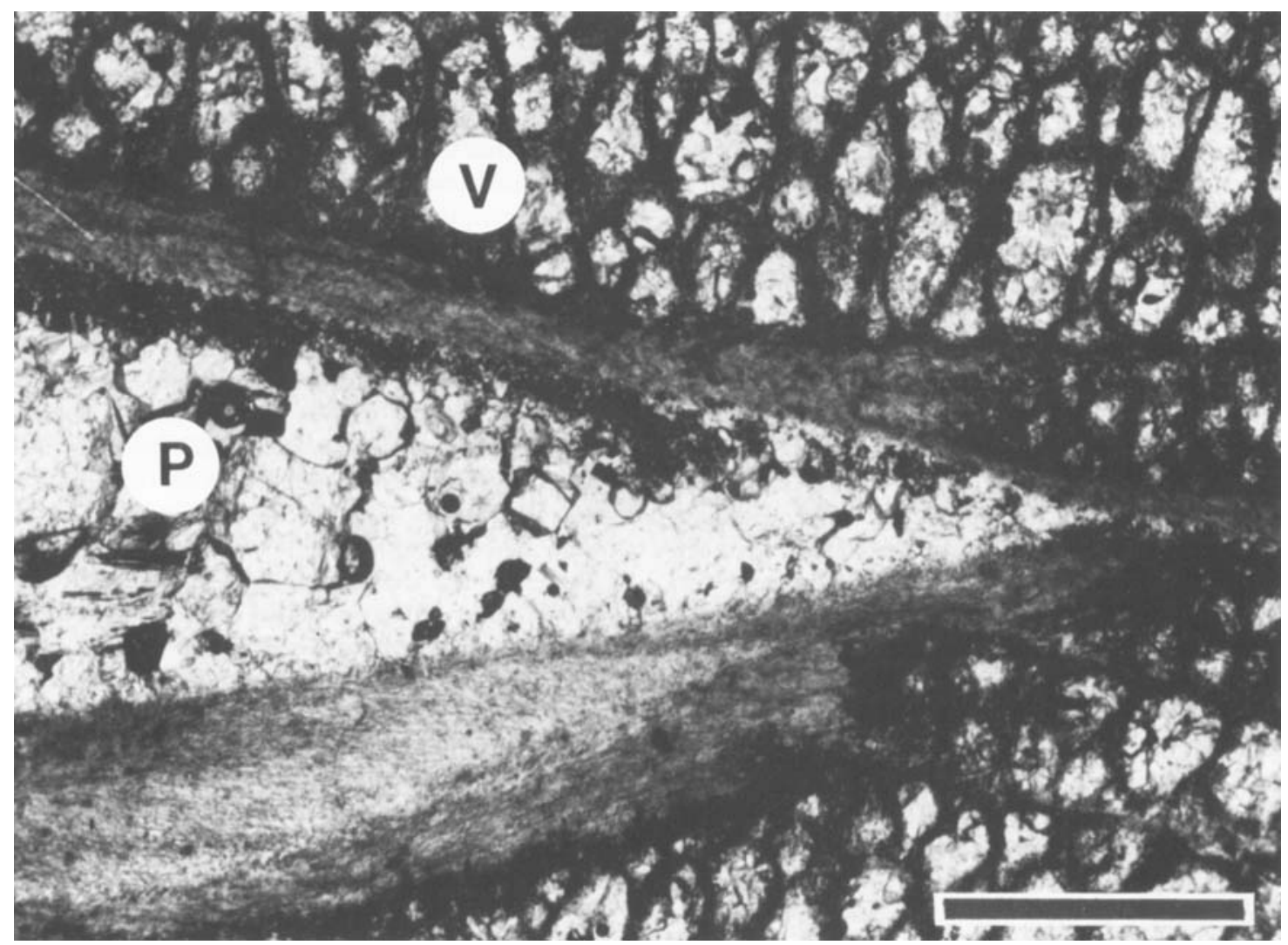

Fig. 3. Two of the representative cement types within the Austin Chalk: intragranular cement infilling pore space within an oyster fragment (P), and finer grained cement occluding the pore space within the vesicular fabric of the oysters (V). This sample is from the Standifer core at $707 \mathrm{~m}$ depth (scale bar equals $500 \mu \mathrm{m}$ ).

Microstyolites (Wanless, 1979) are ubiquitous while true styolites occur infrequently and are restricted to the less fossiliferous and less argillaceous sections. Fractures are uncommon but where present are generally occluded with equant calcite cements.

The void-filling cements found in these rocks are generally very fine grained $(50-1500 \mu \mathrm{m})$. A large percentage of cement probably occurs as overgrowths on coccoliths within the matrix. Although these cements cannot be distinguished petrographically, SEM examination suggests that original coccolith material is obscured by these cements. Coarser grained cements are dominantly restricted to intragranular voids within the vesicular fabric of the oysters and the interior of foraminifera tests, calcispheres, and worm tubes (Fig. 3). Only in the Longhorn outcrop where early dissolution has produced secondary porosity, are coarse grained intergranular cements common.

\section{Cathodoluminescence}

Cathodoluminescence has become a popular tool in carbonate petrography for the investigation of diagenetic fabrics not always visible with a normal petrographic microscope. In carbonates, it is generally believed that manganese $\mathrm{Mn}^{2+}$, substituted into regular lattice sites in the crystalline structure, is the principle activator and ferrous iron the principal inhibitor of luminescence. The concentrations of these

Fig. 2. (A) Mechanical compaction, such as in this fractured Inocermus, is common within the Austin Chalk (Standifer core; $702 \mathrm{~m}$; scale bar equals $300 \mu \mathrm{m}$ ). (B) The interpenetration of this oyster fragment (O) into a prismatic Inoceramus fragment (I) along a solution seam contact is an example of common chemical compaction features (Hurts core, $1387 \mathrm{~m}$; scale bar equals $500 \mu \mathrm{m})$. 
elements necessary either to induce or quench luminescence are not well documented. Estimates of the minimum concentration of $\mathrm{Mn}^{2+}$ required to induce luminescence range from 100 to $1000 \mathrm{ppm}$ (Meyers, 1974), although Pierson (1981a) has reported luminescence in calcite with concentrations of $\mathrm{Mn}^{2+}$ as low as $80 \mathrm{ppm}$. Iron, however, in concentrations in excess of $10,000 \mathrm{ppm}$ will quench luminescence with complete extinction occurring in dolomites with concentrations greater than $15,000 \mathrm{ppm}$ (Pierson, 1981b).

In oxygenated marine waters most manganese is in the form of manganese oxides, resulting in an average dissolved $\mathrm{Mn}^{2+}$ content of only $2 \times 10^{-4} \mathrm{ppm}$ and a range of concentrations extending from $5.0 \times 10^{-5}$ to $8.8 \times 10^{-4} \mathrm{ppm}$ (Holland, 1978, table 5.2). Although suggested values for the distribution coefficient of $\mathrm{Mn}$ into calcite range from 5.4 to 1700 (Brand \& Veizer, 1980 , fig. 1), the small amount of dissolved $\mathrm{Mn}^{2+}$ available makes it impossible for sufficient manganese to be incorporated into the calcite structure necessary to induce luminescence. Therefore, carbonate precipitated from oxygenated marine waters is non-luminescent, including all biogenic carbonate, with rare exception being barnacles (Glover, 1977).

In contrast, studies of the chemistry of interstitial waters in pelagic sediments suggest that dissolved $\mathrm{Mn}^{2+}$ content of pore waters increases dramatically downcore from the sediment-water interface (Bischoff \& Sayles, 1972; Gieskes, 1973; Sayles \& Manheim, 1974; Glover, 1977). As the sediments are buried the environment changes from oxidizing to reducing, initiating reduction of the solid manganese oxides. In the vicinity of this oxidation-reduction boundary, dissolved $\mathrm{Mn}^{2+}$ may increase to concentrations in excess of $50 \mathrm{ppm}$. With increased burial $\mathrm{Mn}^{2+}$ concentrations stabilize to $4.5 \mathrm{ppm}$, apparently reflecting equilibrium with a diagenetic carbonate phase (Lynn \& Bonatti, 1965).

In contrast, ferrous iron does not show a comparable downcore increase. In marine waters, dissolved $\mathrm{Fe}^{2+}$ has an average abundance of $2.0 \times 10^{-3} \mathrm{ppm}$ (the range is between $10^{-4}$ and $6.0 \times 10^{-2} \mathrm{ppm}$ ) (Holland, 1978 , see table 5-2) and a distribution coefficient ranging from $I$ to 20 (Brand \& Veizer, 1980, Fig. 1). However, under reducing conditions the iron compounds formed in the marine environment are more stable than the manganese oxides and dissolved $\mathrm{Fe}^{2+}$ is preferentially reprecipitated as pyrite and other iron sulphides rather than remaining in solution (Krauskopf, 1957). Therefore, diagenetic calcite precipitating from marine-derived, interstitial pore waters luminesces, with the degree of luminescence depending on $\mathrm{Mn}^{2+}$ and $\mathrm{Fe}^{2+}$ content. In light of these relationships, luminescence can be applied as an effective indicator of secondary calcite precipitation within burial diagenetic environments.

Non-luminescence represents either: (1) original calcite precipitated from marine waters or (2) diagenetic calcite containing high concentrations of $\mathrm{Fe}^{2+}$ or very low concentrations of $\mathrm{Mn}^{2+}$ (i.e. no source). Because primary biogenic carbonate does not luminesce, bioclasts which luminesce must reflect diagenetic alteration of the original skeletal carbonate. Therefore, primary marine calcites can be discriminated from secondary diagenetic calcites on the basis of luminescence. Thus, analysis of the non-luminescent components should provide the best estimate of initial marine isotopic compositions.

All luminescence work employed a Nuclide Corporation Luminoscope, model ELM-2a, mounted on a Leitz monocular research microscope with a maximum magnification capability of $400 \mathrm{x}$ utilizing universal stage objectives. Standard operating conditions were an accelerating potential $12 \mathrm{kV}$ at $0.8 \mathrm{~mA}$ beam current with a focused beam diameter of approximately $5 \mathrm{~mm}$. Samples used were epoxy mounted thin sections and highly polished chips. Paired reflected and luminescent photomicrographs were prepared in order to record areas for subsequent microsampling for chemical analysis.

These rocks exhibit an orange-yellow luminescence (590-630 $\AA$ ) (Sommer, 1972), with the exception of phosphate-rich zones which luminesce a pale blueviolet. The intensity of luminescence in calcite was visually divided into three arbitrary categories: (1) very luminescent (brilliant orange in colour); (2) moderately luminescent (dull to moderately bright orange in colour); (3) non-luminescent (extinguished, black in colour). In general all rocks in the studied interval luminesce with the degree of overall luminescence positively correlated to the abundance of carbonate relative to clay. Skeletal components show the most marked variation in luminescence, ranging from homogeneously non-luminescent to very luminescent. More often, luminescence is heterogeneous even at the scale of individual bioclasts (Fig. 4). This may occur in two manners, concentric or patchy luminescence. Concentric replacive patterns of luminescence are most common among the Inoceramus, and appear to reflect increased diagenetic alteration on the surface of the skeletal fragment. Patchy luminescence probably reflects the heterogeneous replacement of bioclasts along growth lamellae or within pores formally 
occupied by the organic matrix. In contrast the micritic matrix comprized of pellets and coccoliths, and all intergranular and fracture-filling carbonate cements are pervasively luminescent. Non-luminescent calcite was observed only as isolated portions of large bioclasts.

\section{Carbon and oxygen isotopic analysis}

Four components were isolated for analysis of carbon and oxygen isotopic composition: Inoceramus, oysters, micrite, and cements. Microsamples were taken in areas of homogeneous luminescence and categorized according to the intensity of luminescence. In the case of both oysters and Inoceramus, all three intensities of luminescence were present and material representative of each was sampled.

Microsampling for isotopic analysis was performed on a microscope-mounted drill assembly with a manually controlled $X-Y$ translation stage. This microsampler provides for accurate removal of sample materials from areas as small as $100 \mu \mathrm{m}$. The majority of analyses performed in this study represent sampled areas at a scale of approximately $500 \mu \mathrm{m}$ providing approximately $0.2-0.5 \mathrm{mg}$ of powdered carbonate. Although $100 \mu \mathrm{m}$ resolution drill bits were employed for the isolation of cement components, some contamination of the pure cement with the enclosing matrix is still possible.

All carbonate powdered samples were roasted at $380^{\circ} \mathrm{C}$ in vacuo for $1 \mathrm{hr}$ to remove volatile organic contaminants and subsequently reacted with anhydrous phosphoric acid at $50^{\circ} \mathrm{C}$ in an extraction line coupled directly to the inlet of a VG Micromass 602E ratio mass spectrometer in the Stable Isotope Laboratory of the University of Michigan. Isotopic enrichments were measured relative to a lab standard gas (KIS-1) which has been calibrated relative to PDB through daily analysis of NBS-20 powdered carbonate standard $\left(-4.14 \delta^{18} \mathrm{O} ;-1.06 \delta^{13} \mathrm{C}\right)$. After conversion to PDB, all enrichments were corrected for ${ }^{17} \mathrm{O}$ contribution according to the procedure of Craig (1957).

Analytic precision was continuously monitored by daily analysis of NBS-20 and by duplication of a minimum of $10 \%$ of all samples. Precision was maintained better than $0.1 \%$ for both carbon and oxygen. The heterogeneity of composition within individual carbonate components (cements, bioclasts, etc.) was also evaluated by performing multiple analyses for single grains. Variation introduced by sample heterogeneity is significantly greater than analytic precision.

All data are graphically presented in Figs 5, 6 and 7. Data for the luminescent categories of oysters and micrites are presented in Fig. 5 for each core. Data for carbonate cements and Inoceramus from the Standifer core are displayed in Figs 6 and 7, respectively.

Oysters show little change in isotopic composition among cores, with average oxygen values ranging from $+2.0 \%$ to $+3.0 \%$. There is no systematic relationship between variation in oxygen isotopic composition of oysters with either the degree of luminescence and depth of burial. On the other hand, average carbon values become lighter with increasing luminescence, but still exhibit no correlation with burial depths among cores.

Micrites also display a similar variation in oxygen values, ranging from approximately $-3 \cdot 2 \%$ to $-4.2 \%$ and yield carbon compositions even lighter than the most luminescent oysters averaging between 1.0 and $1.5 \%$. Micrites show no significant correlation with burial depth in either oxygen or carbon composition.

Cement compositions are more variable in $\delta^{18} \mathrm{O}$; averages for individual cores range between -3.0 and $-5.5 \%$. Within individual cores minimum and maximum values show even greater variation. Because most cements are very fine and difficult to sample, some of this variation may be due to minor contamination $(10-20 \%)$ with matrix carbonate. Pure cement separates were obtained only from fracture related calcite.

Figure 7 represents Inoceramus data from the Standifer core $(679-710 \mathrm{~m})$. Dashed lines connect replications of an individual skeletal piece. Inoceramus data show no trends either within or between cores. Notably these analyses are compatible with analyses of oysters.

\section{DISCUSSION}

Previous workers have suggested that within chalk deposits, cementation progresses with depth of burial (Matter, 1974; Schlanger \& Douglas, 1974; Hancock \& Scholle, 1975; Scholle, 1977). Thus, it would be expected that a change in isotopic composition would be observed for cements precipitated at increasing burial depths reflecting the increasing diagenetic temperatures. If progressive diagenesis occurred in equilibrium with ambient temperatures, this model 

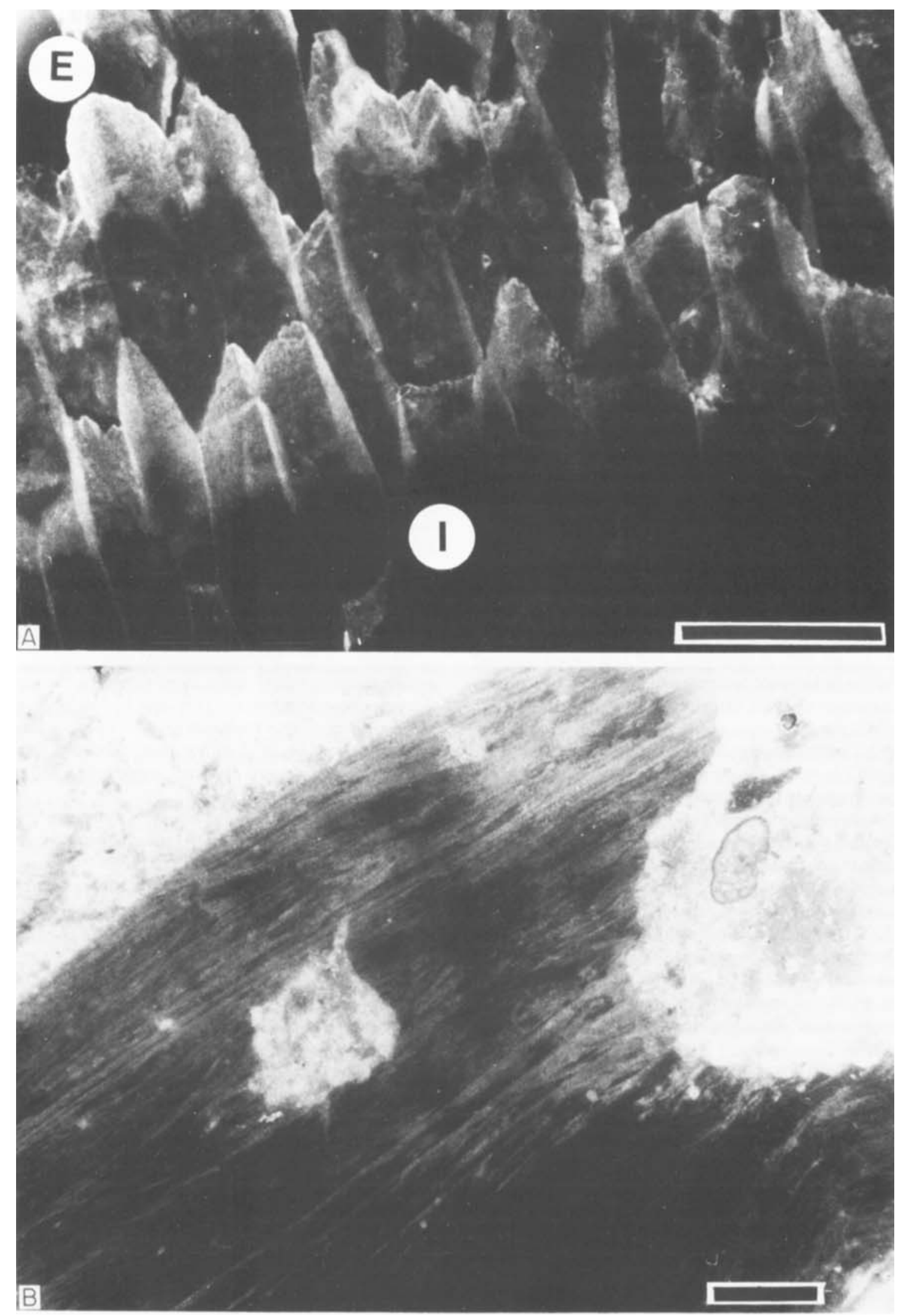
would predict increasingly lighter oxygen isotopic compositions. For this study area, application of a reasonable geothermal gradient of $30^{\circ} \mathrm{C} \mathrm{km}^{-1}$ (Dickey, 1979) would give a maximum diagenetic temperature of approximately $80^{\circ} \mathrm{C}$, reflecting a depth range of $2400 \mathrm{~m}$. Therefore, by temperature considerations alone, we would expect approximately a $16 \%$ variation in the oxygen isotopic compositions of the precipitated cements. However, the average $\delta^{18} \mathrm{O}$ values exhibit only minor oxygen variation ranging from -3.0 to $-5.0 \%$. In order to interpret this discrepancy it is necessary to consider the overall diagenetic system of the Austin.

If the effects of diagenesis in the Austin are to be discriminated, it is first necessary to determine the original, starting composition of the marine sediment. The components most suited for such a determination are those bioclasts which petrographically appear unaltered. In this study cathodoluminescence has been employed as an indicator of diagenesis. Most organisms precipitate non-luminescent skeletal calcite; in contrast, diagenetic calcites formed within marine burial environments are pervasively luminescent. Therefore, our best estimate of original, prediagenetic composition of the sediment should be contained in skeletal material which is non-luminescent. Since progressive diagenesis should result in precipitation of calcite with lighter $\delta^{18} \mathrm{O}$ values, we would expect luminescent diagenetic calcites to possess lighter isotopic signatures than non-luminescent calcites which should possess the heaviest carbon and oxygen signatures. This was observed in the compositional variation among specimens showing differences in luminescence.

Oyster components were chosen for estimation of original composition (Fig. 5), particularly since oysters are thought to precipitate calcite in isotopic equilibrium with seawater (Lowenstam \& Epstein, 1954). Carbon-oxygen plots of oyster analyses indicate that with progressive change in luminescence of the oyster bioclasts, $\delta^{18} \mathrm{O}$ shows only minor variation while $\delta^{13} \mathrm{C}$ decreases with increasing luminescence. Not only are these observations consistent within individual cores, but also among cores across the burial depth profile.
Inoceramus were also studied. The prismatic layer of Inoceramus was originally deposited as low magnesium calcite (Bathurst, 1975), suggesting a greater resistance to diagenetic alteration. Preliminary analysis of Inoceramus concentrated on the Standifer core (Fig. 7). In general, isotopic compositions for Inoceramus show large variations within individual cores and less consistent trends than oysters. Moreover, conclusions by Tourtelot \& Rye (1969) in their work on the late Cretaceous fauna of the western interior of North America suggest that Inoceramus did not deposit their shell in oxygen isotopic equilibrium. Thus the approach of using Inoceramus for determining original isotopic compositions was not pursued further.

Analysis from the Longhorn outcrop and the Preuse core are exceptions to the trend observed in oysters and Inoceramus from other cores. The Longhorn samples are consistently lighter in average oxygen and carbon compositions than the other localities, although mimicking the same general trends. A probable cause of this deviation is outcrop exposure to meteoric waters resulting in the diagenetic alteration of skeletal components such that they no longer retain original signatures. On the other hand, the oxygen values for the oysters of the Preuse core fall within the range of data for the other cores, but do not display any discernable trend. Although the carbon values decrease with increasing luminescence, they are consistently lighter than those of other cores. These isotopic compositions may be a function of elevated temperatures in the vicinity of the Preuse core due to contemporaneous late Cretaceous intrusion of serpentine plugs (Anderson \& Schneiderman, 1973; Young, Barker \& Jonas, 1975).

With these exceptions, $\delta^{18} \mathrm{O}$ composition of oysters is essentially invariant among the remaining six cores both with changing luminescence and burial depth. The observed decrease in carbon isotopic composition with increasing luminescence may result from oxidation of marine organic matter in the sediment, with concommitant production of light carbon $\mathrm{HCO}_{3}^{-}$ (e.g. Irwin, Curtis \& Coleman, 1977). Calcite precipitating from such sources would have lighter $\delta^{13} \mathrm{C}$ values than the original skeletal carbonates. Notably,

Fig. 4. (A) This photomicrograph displays the luminescence pattern common within Inoceramus fragments. Luminescence is more pronounced along the exterior surfaces (E) with a general decrease in luminescence toward the interior of fragments (I) producing this pseudo-zoned pattern. Note, however, that luminescent intergrowths may extend inward along the boundaries between non-luminescent prisms. This suggests that the heterogeneous nature of replacive diagenesis is controlled in part by the accessibility to diagenetic fluids (Standifer core, $709 \mathrm{~m}$; scale bar equals $200 \mu \mathrm{m}$ ). (B) Oysters commonly exhibit a patchy luminescence with diagenetic replacement mimicking the foliated skeletal microstructure. Brightly luminescent areas within this fragment are micrite-filled bores (Standifer, $706 \mathrm{~m}$; scale bar equals $200 \mu \mathrm{m}$ ). 

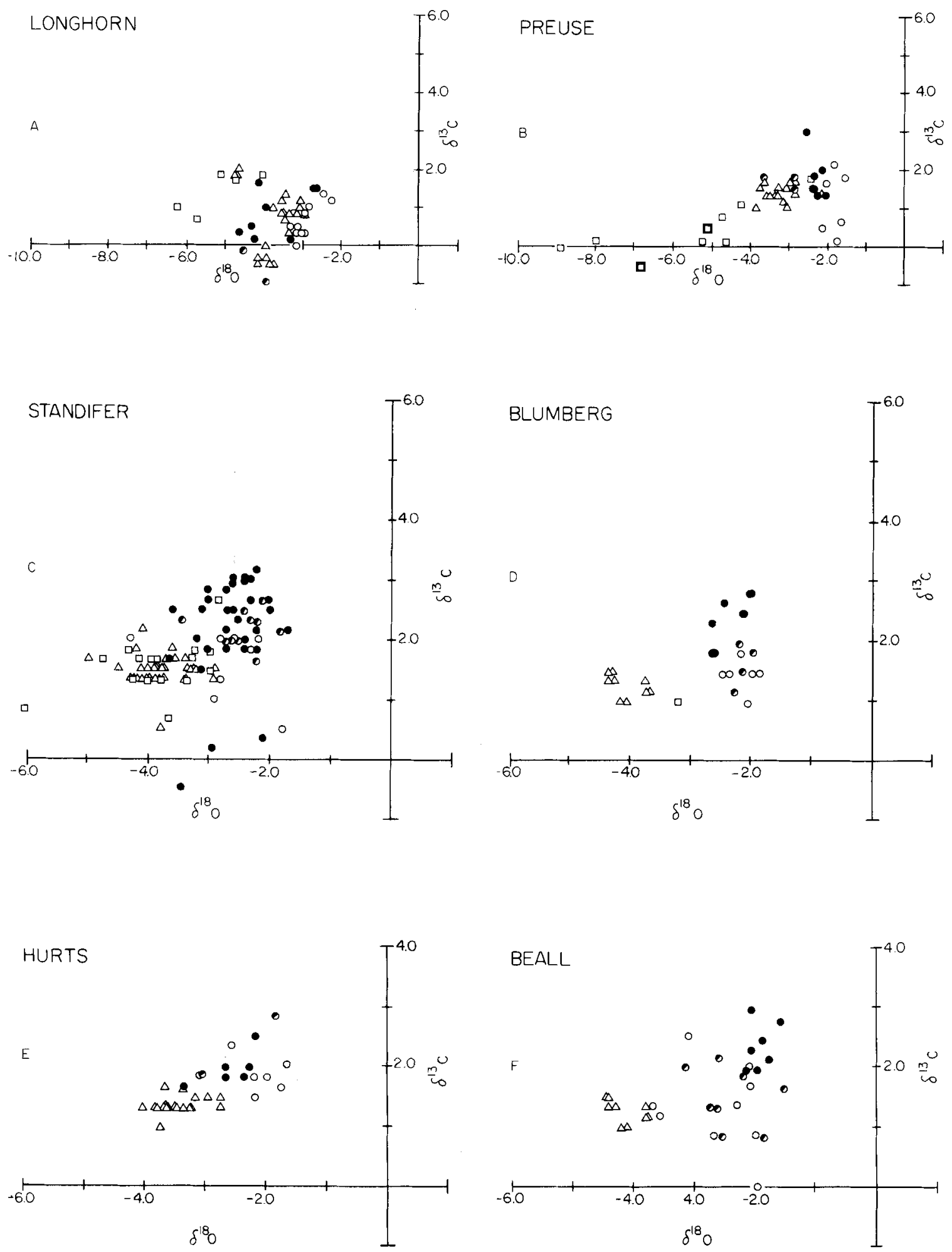

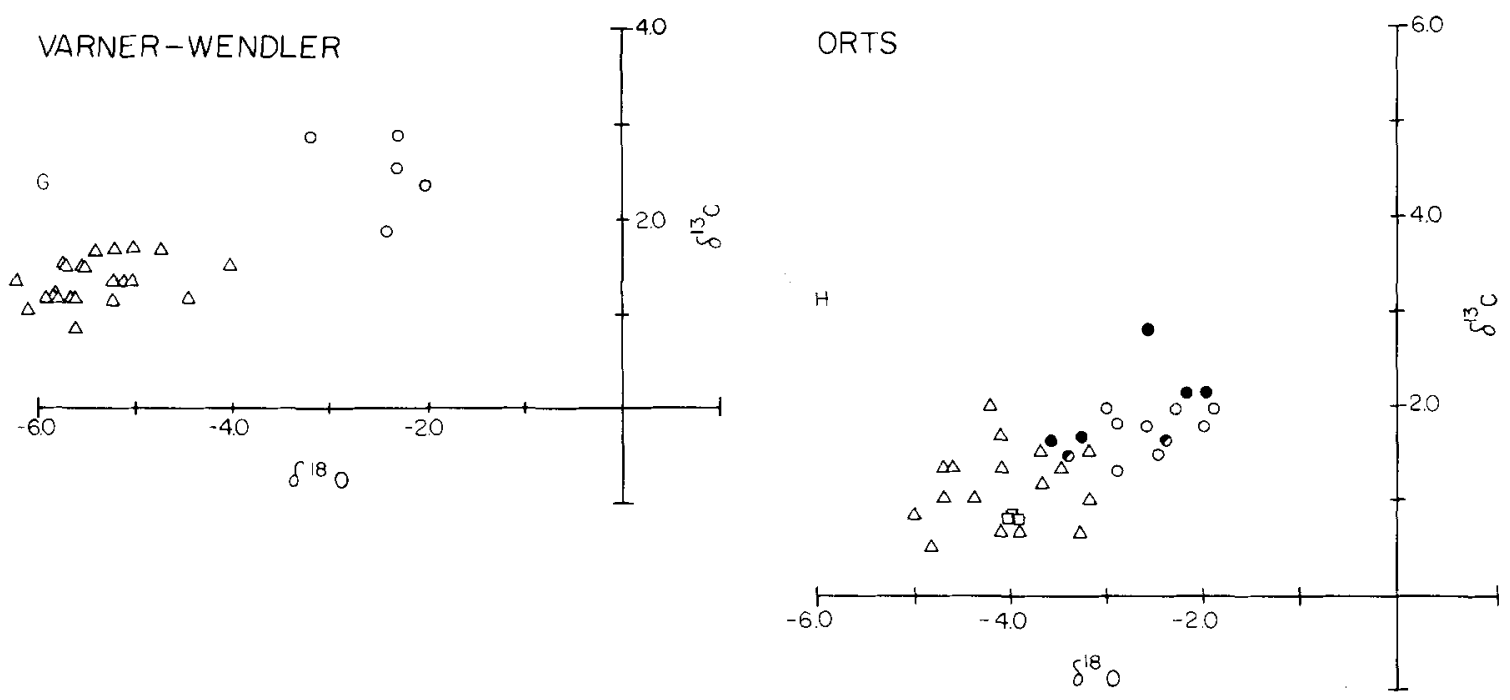

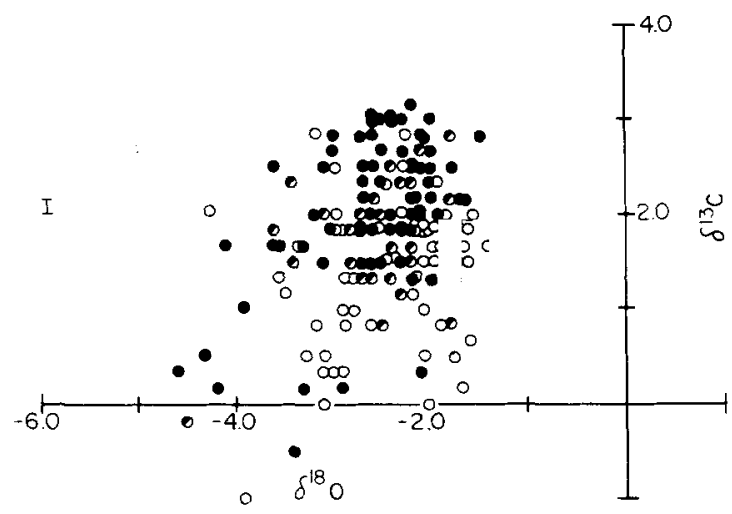

we observed no evidence of positive carbon isotopic compositions indicative of anaerobic decomposition reactions of organic material (Curtis, Petrowski \& Oertel, 1972). In light of these data, our estimate for original isotopic composition is $-2.0 \% \delta^{18} \mathrm{O}$ and $3.0 \%$ o $\delta^{13} \mathrm{C}$. This estimate is based on a mean of all non-luminescent oysters and is conservative since the heaviest oyster compositions range up to $-1.5 \%{ }^{18} \mathrm{O}$ and $+3 \cdot 1 \%{ }_{0} \delta^{13} \mathrm{C}$. It is, however, compatible with the compositions of calcite that would precipitate at sea surface temperatures from a $-1.2 \% \delta^{18} \mathrm{O}$ marine water (Shackleton \& Kennett, 1975).

Diagenesis of the Austin chalk was further documented by isotopic analysis of the micrite fraction. Micrites are free of coarse fossil debris and consist almost entirely of low magnesium calcite coccoliths and their associated cement overgrowths. Previous workers (McIntyre, 1967; Douglas \& Savin, 1975;
Fig. 5. (A-H) These plots display carbon and oxygen isotopic analyses for oysters, micrite, and cements for individual cores: non-luminescent oysters 0 ; patchy luminescent oysters - highly luminescent oysters $O$; micrites $\triangle$; and cements $\square$. (1) In this compilation of oyster data from all cores, a progressive decrease in the carbon isotopic composition can be seen with increasing luminescence. Nonluminescent oysters $(\mathbf{O})$ cluster dominately at the heaviest carbon-oxygen compositions and provide our best estimate of initial marine carbonate composition $\left(-2.0 \% \delta^{18} \mathrm{O}\right.$ and $+3.0 \% \delta^{13} \mathrm{C}$ ). Moderately luminescent oysters $(0)$ and highly luminescent oysters $(O)$ show a progressive decrease in carbon and oxygen isotopic composition trending toward the diagenetic fields of cements and micrites.

Margolis et al., 1975; Anderson \& Steinmetz, 1981) have used coccoliths for palaeotemperature work, and their results indicate that coccoliths precipitate calcite in isotopic equilibrium with seawater. The volume of the calcite cement contributed by overgrowths, however, may be $50-200 \%$ of the initial volume of the nannofossil (Bukry, 1973; Roth, 1973; Douglas \& Savin, 1975; Matter et al., 1975). Unfortunately, original coccolith plates are difficult to distinguish petrographically from overgrowth cements and as such cannot be adequately separated for microanalysis. Therefore, analysed micrites are a mixture of original skeletal carbonate precipitated in surface waters and cements precipitated during diagenesis. Any deviation from original isotopic composition therefore reflects contamination by overgrowth cement. Although not a measure of the pure diagenetic endmember, the 'mixed signal' isotopic signature of 


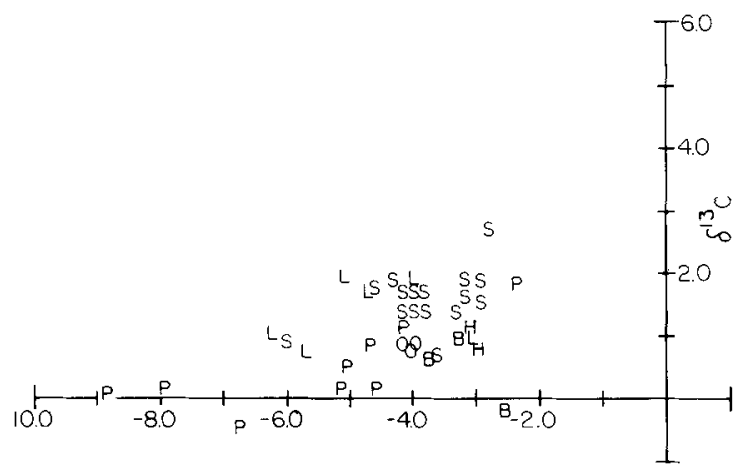

Fig. 6. Carbon-oxygen isotopic compositions of cements in the Austin Chalk lie within the range of micrites and do not exhibit a systematic variation with burial depth. Light oxygen compositions are observed only in cements from the Preuse core $(\mathrm{P})$ in which anomolously high temperatures were present due to associated serpentine intrusives. Longhorn (L), Preuse (P), Standifer (S), Blumberg (B), Hurtz (H) and Orts (O).

the micrite still provides a valuable record of the diagenetic history.

Data for micrite and oysters are presented in Fig. 5. Within an individual locality, micrites are consistently lighter in both oxygen and carbon than the associated very luminescent oysters. Oxygen isotopic compositions for the micrites range from $-3 \cdot 2$ to $-5.4 \%$, and eliminating the Longhorn outcrop for reasons outlined above, the overall average is $-3.9 \%$. There is little change in the carbon and oxygen composition of the micrites between cores across the burial depth profile. If cementation was indeed progressive and more extensive with burial, we would expect lighter oxygen isotopic compositions for overgrowth cements precipitated at higher diagenetic temperatures and under deeper burial conditions. Any shift in the isotopic composition of the cements should also be observed in the micrites, due to the abundance of cement which comprise them.

Average micrites display a 1.0 to $1.5 \%$ shift in $\delta^{18} \mathrm{O}$ from values obtained for associated non-luminescent oysters. Assuming that the change in oxygen composition reflects only a change in temperature and that the micrites are entirely overgrowth cement, this shift in oxygen isotopic composition would require formation of the cement at a temperature $5-8^{\circ} \mathrm{C}$ higher than the oysters. Applying a geothermal gradient of $30^{\circ} \mathrm{C}$ $\mathrm{km}^{-1}$ (Dickey, 1979) and assuming constant surface and bottom water temperatures, it is then possible to estimate a minimum burial depth of $200-300 \mathrm{~m}$ for the lithification of micrites. If bottom waters were

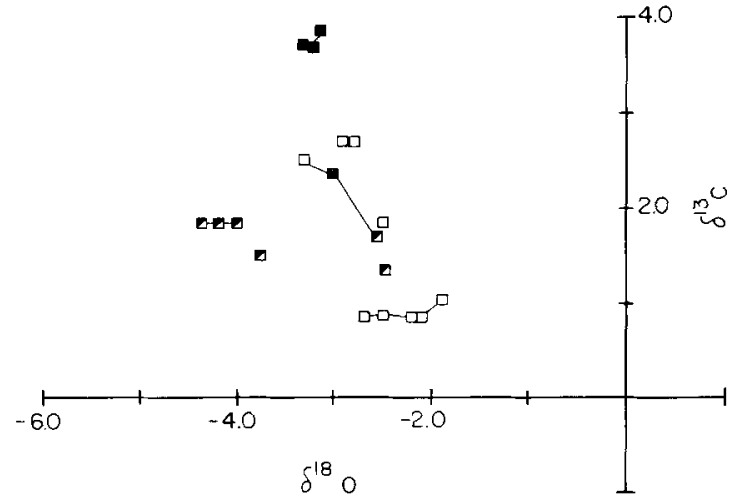

Fig. 7. Carbon-oxygen isotopic analyses of Inoceramus from the Standifer core illustrate their high variability in composition. Some of this variation is likely introduced by effects of diagenesis (non-luminescent $\square$; moderately luminescent $\boldsymbol{\square}$; and highly luminescent $\square$ ). Note that even on the scale of individual specimens (replications connected by solid lines) a significant degree of variability is still present. These Inoceramus samples are from the Standifer core.

sufficiently colder than surface waters, estimates for burial depths at which diagenesis occurred would increase. Moreover, the micrites are not composed entirely of cement, they do retain an original isotopic signature in the skeletal low magnesium calcite. Thus, the oxygen isotopic compositions of the overgrowth cements are probably lighter than those obtained for bulk analysis of the micrites, suggesting that these burial depths represent minimum estimates.

Scholle (1977) has suggested that cementation, especially in terms of cement overgrowths on coccoliths, does not become important until early dewatering and mechanical compaction has reduced porosity to $50 \%$. From this point, overgrowth cementation and pressure solution phenomena become the major porosity reduction mechanisms. Therefore, as porosity decreases there should be an accompanying proportional increase in the volume of cement. Assuming an open diagenetic system, the cement precipitated at successive burial depths and likewise increasing temperatures will have lighter $\delta^{18} \mathrm{O}$ signatures. This would result in a decrease in whole-rock oxygen isotopic composition. Scholle (1977) observed this trend in the chalk data obtained from a variety of localities. Many of these data are derived from DSDP cores where progressive lithification occurs with depth. Notable, however, are hardground samples which he has inferred from whole-rock isotopic analyses. These samples form a unique compositional field characterized by comparatively heavier $\delta^{18} \mathrm{O}$ signatures $(-1.5$ to $-4.0 \%)$ than those for other 
chalks of similar porosities. Although most of the Austin chalk micrites analysed in this study also fall within this hardground field, evidence presented above suggests that our samples were not cemented on the seafloor, as suggested by Scholle (1977), but at depths of at least $200-300 \mathrm{~m}$.

Although isotopic compositions for the micrites are relatively uniform with depth, porosity decreases systematically (see Table 1) and probably reflects an increased volume of cement at greater depths. These late cements should have lighter oxygen isotopic compositions reflecting higher diagenetic temperatures of precipitation. However, the micrites show no correlation between $\delta^{18} \mathrm{O}$ relative to porosity. Hence, the oxygen isotopic composition of these later cements must be very similar to that of the micrites.

This conclusion is supported by analysis of intergranular and fracture-vein cement (Fig. 6). Because cements are of diagenetic origin, and not a mixture of primary and secondary carbonates, they should most accurately reflect the conditions of precipitation in the marine burial environment. Pure separates of intragranular cements are indistinguishable in composition from micrites, and average less than $2.0 \%^{-1}$ lighter in oxygen than the starting marine composition (non-luminescent oysters). Significantly, even fracture-vein cements, which definitely post-date the majority of micrite lithification, have similar compositions. These cements, which occur only in the deepest cores, do not possess an isotopic signature characteristic of precipitation at higher temperatures.

The similarity in composition between these components could indicate that the majority of diagenesis took place within a restricted depth interval. This would include intergranular cementation, pressure solution, brittle fracturing and vein calcite cementation. The range in oxygen isotopic composition would define the depth interval over which diagenesis had occurred, and on the basis of micrite and cement data, this would represent a minimum depth of $200-300 \mathrm{~m}$ and a maximum depth of $600-800 \mathrm{~m}$. If this model were correct, once the sediment column had passed through this diagenetic window, further diagenesis must have been insignificant, for no evidence of this diagenesis is recorded in the isotopic signature. However, this model is incompatible with petrographic data. Fracture-vein calcites occur only in the deepest cores, all of which have been buried in excess of $1000 \mathrm{~m}$, well beyond the estimated burial depth limits calculated from oxygen isotopic compositions. Even though these fractures clearly post-date chalk lithification and must have formed at greater burial depths, this is not reflected in their isotopic compositions.

We do not favour this simplistic model for Austin Chalk diagenesis. Rather, we suggest that progressive diagenesis with depth was active and that the lack of its reflection in isotopic signatures results from diagenesis in an effectively closed, rock-dominated system. Implicit in the above model is an assumption that the diagenetic porewater system was open, whereby the composition of porewaters did not change significantly downcore from their original marine composition. This assumption is unrealistic when the nature of porewater flow in marine burial environments is considered. In the absence of thermally induced convection, such as in the vicinity of the Preuse core, diagenetic porewaters are effectively stagnant (Longman, 1980). Advective porewater flow is driven only by compactional processes which force intergranular porewaters upward as pores collapse. This process does not provide for recharge of porewaters from marine sources. Moreover, since water acts as the medium through which diagenetic reactions are cycled (Sayles \& Manheim, 1975; Lawrence, 1973), diagenesis will progressively modify its chemical and isotopic composition until equilibrium is achieved between the porewater and the dissolving and precipitating mineral phases.

This phenomenon is of particular importance when considering the isotopic composition of diagenetic carbonates in rock-dominated (high rock/water volume ratio) carbonate systems (Meyers \& Lohmann, 1984). In such cases, a single volume of porewater may be cycled through multiple solution-precipitation reactions. Equilibration can be rapidly achieved such that isotopic compositions of precipitating carbonate cements will be identical in composition to the dissolving carbonates which are driving cementation. For example in a low porosity sediment where pressure solution processes are active, the composition of cements precipitated in fractures and intergranular pores will be identical in composition to the dissolving carbonates. Hence, for the Austin Chalk we envision a closed diagenetic system during the emplacement of intergranular and fracture-vein cements. Such a model is compatible with petrographic observations of the Austin Chalk including decreasing porosity and increasing pressure solution and fracturing which clearly indicate a progression of diagenesis related to depth.

An overriding conclusion of this study was the realization that the isotopic composition of precipitating phases may be independent of their temperature 
of emplacement and, thus, may not accurately record systematic changes in temperature which might have occurred during diagenesis. Rock-dominated, closed diagenetic systems are applicable not only to marine burial environments, but to all diagenetic systems where porewaters are cycled through multiple solutionprecipitation reactions and porewater composition is progressively modified. This includes both large-scale systems such as shallow meteoric phreatic systems where porewater composition evolves progressively along groundwater flow lines as well as the microscale diagenetic processes of metastable diagenesis. In this light, we urge caution when interpreting isotopic compositions of diagenetic carbonates unless the degree of openness of the diagenetic system is known. Oxygen isotopic signatures may bear no resemblance to rock-water temperatures at which they were precipitated.

\section{ACKNOWLEDGMENTS}

We wish to thank the Kaiser Cement and Gypsum Corporation for allowing access to their quarry; Rice University for providing core material and laboratory space for their description; and Amoco Production Company for loan of the Varner-Wendler core. Jeff Dravis provided a wealth of initial information and the porosity analyses for the Austin. The quality of this manuscript was enhanced by the critical reviews provided by J. D. Marshall and J. Hudson. This research was supported by National Science Foundation Grants EAR 79-20786 and EAR 81-15480 and a grant from Marathon Oil Company.

\section{REFERENCES}

Anderson, T. F. \& SchneidermanN, N. (1973) Stable isotope relations in pelagic limestones from the central Caribbean: Leg 15, Deep Sea Drilling Project. Init. Rep. Deep Sea drill. Proj. 15, 795-803.

ANDERSON, T. F. \& SteinmetZ, J. C. (1981) Isotopic and biostratigraphic records of calcareous nannofossils in a Pleistocene core. Nature, 294, 741-744.

Bathurst, R.G.C. (1975) Carbonate Sediments and their Diagenesis. Elsevier, Amsterdam. 658 pp.

Beall, A.O. \& Fisher, A.G. (1969) Sedimentology. Init. Rep. Deep Sea drill. Proj. 1, 521-593.

Bischoff, J.L. \& SAYles, F.L. (1972) Pore fluid and mineralogical studies of recent marine sediments: Bauer Depression region of East Pacific Rise. J. sedim. Petrol. 42, 711-724.
Brand, U. \& Veizer, J. (1980) Chemical diagenesis of a multicomponent carbonate system -1 : Trace elements. $J$. sedim. Petrol. 50, 1219-1236.

Bukry, D. (1973) Coccolith stratigraphy, eastern equatorial Pacific, Leg 16. Init. Rep. Deep Sea drill. Proj. 16, 653-712.

CRAIG, H. (1957) Isotopic standards for carbon and oxygen, correction factors for mass spectrometric analysis of carbon dioxide. Geochim. Cosmochim. Acta. 12, 133-149.

Curtis, C.D., Petrowski, C. \& Oertel, G. (1972) Stable carbon isotope ratios within carbonate concretions: a clue to place and time of formation. Nature, Phys. Sci. 235, 98 100.

Dickey, P.A. (1979) Petroleum Development Geology. Petroleum Publishing Co., Tulsa, 398 pp.

Dickson, J.A.D. \& Coleman, M. (1980) Changes in carbon and oxygen isotope composition during limestone diagenesis. Sedimentology, 27, 107-118.

Douglas, R.S. \& Savin, S.M. (1975) Oxygen and carbon isotopic analyses of Tertiary and Cretaceous microfossils from Shatsky Rise and other sites in the North Pacific Ocean. Init. Rep. Deep Sea drill. Proj. 32, 509-520.

Dravis, J.J. (1979) Sedimentology and diagenesis of the Upper Cretaceous Austin Chalk Formation, South Texas and Northern Mexico. Ph.D. Dissertation, Rice University. $513 \mathrm{pp}$.

DunNington, H.V. (1967) Aspects of diagenesis and shape change in stylolitic limestone reservoirs. Proc. 7 th World Petroleum Cong., Mexico City. 2, 339-352.

EADE, J.V. \& ANDERSON, T.F. (1974) Oxygen and carbon isotope composition diagenesis of Eocene clay nannochalk at DSDP sit 287, Coral Sea Basin, leg 30. Init. Rep. Deep Sea drill. Proj. 30, 419 422.

GiEsKeS, J.M. (1973) Interstitial water studies, Leg 15. Init. Rep. Deep Sea drill. Proj. 15, 831-850.

Glover, E.D. (1977) Cathodoluminescence, iron and manganese content and the early diagenesis of carbonates. $\mathrm{Ph} . \mathrm{D}$. Dissertation, University of Wisconsin-Madison, $444 \mathrm{pp}$.

HANCOCK, J.M. \& SCHOLLE, P.A. (1975) Chalk of the North Sea. In: Petroleum and the Continental Shelf of north-west Europe, vol. I (Ed. by A. W. Woodland), pp. 413-425. Wiley, New York.

Holland, H.D. (1978) The Chemistry of the Atmosphere and Oceans. Wiley, New York. $351 \mathrm{pp}$.

Hudson, J.D. (1977) Stable isotopes and limestone lithification. J. geol. Soc. London, 133, 637-660.

Irwin, H., Curtis, C. \& Coleman, M. (1977) Isotopic evidence for source of diagenetic carbonates formed during burial of organic-rich sediments. Nature, 269, 209213.

KRAUSKOPF, K.B. (1957) Separation of manganese from iron in sedimentary processes. Geochim. Cosmochim. Acta. 12, 61-84.

LAWRENCE, J.R. (1973) Interstitial water studies, Leg 15stable oxygen and carbon isotope variations in water, carbonates, and silicates from the Venezuela Basin (Site 149) an the Aves Rise (Site 148). Init. Rep. Deep Sea drill. Proj. 20, 891-899.

LongmaN, M.W. (1980) Carbonate textures from near surface diagenetic environments. Bull. Am. Ass. Petrol. Geol. 64, 461-487.

Lowenstam, H.A. \& Epstein, S. (1954) Paleotemperatures of the post-Aptian Cretaceous as determined by the oxygen isotope method. J. Geol. 62, 207-248. 
LyNN, D.C. \& BonatTI, E. (1965) Mobility of manganese in diagenesis of deep-sea sediments. Mar. Geol. 3, 457-474.

MaRGolis, S.V. et al. (1975) Oxygen and carbon isotopes from calcareous nannofossils as paleooceanographic indicators. Science, 189, 555-557.

MATTER, A. (1974) Burial diagenesis of pelitic and carbonate deep-sea sediments from the Arabian Sea. Init. Rep. Deep Sea drill. Proj. 23, 421-469.

Matter, A., Douglas, R.G. \& Perch-Nielsen, K. (1975) Fossil preservation, geochemistry, and diagenesis of pelagic carbonates from Shatsky Rise, northwest Pacific. Init. Rep. Deep Sea drill. Proj. 32, 891-921.

MCINTYRE, A. (1967) Coccoliths as paleoclimatic indicators of Pleistocene glaciation. Science, 158, 1314-1317.

MEYERS, W.J. (1974) Carbonate cement stratigraphy of the Lake Valley Formation (Mississippian) Sacramento Mountains, New Mexico. J. sedim. Petrol. 44, 837-861.

MeYers, W.J. \& LoHMANN, K.C. (1984) Isotope geochemistry of regionally extensive calcite cement zones and marine components in Mississippian limestones, New Mexico. In: Carbonate Cements Revisited (Ed. by P. Harris and N. Schneiderman). Spec. Publs Soc. econ. Paleont. Miner., Tulsa. (In press)

Murray, G.E. (1961) Geology of the Atlantic and Gulf Coastal Province of North America. Harper Brothers, New York. $692 \mathrm{pp}$.

Neugebauer, J. (1973) The diagenetic problem of chalk. The role of pressure solution and pore fluid. Neur. Jb. Geol. Paläont. Mh. 143, 136-156.

Neugebauer, J. (1974) Some aspects of cementation in chalk. In: Pelagic Sediments: on Land and under the Sea (Ed. by K. J. Hsü and H. C. Jenkyns). Spec. Publs int. Ass. Sediment. 1, 149-176. Blackwell Scientific Publications, Oxford.

PIERSON, B.J. (1981 a) Late Cenozoic geology of the southeastern Bahama Banks. Ph.D. Dissertation, University of Miami (RSMAS)

Pierson, B.J. (1981b) The control of cathodoluminescence in dolomite by iron and manganese. Sedimentology, $\mathbf{2 8}$, $601-610$.
Roth, P. (1973) Calcảreous nannofossils, Leg 17. Init. Rep. Deep Sea drill. Proj. 17, 695-795.

SAYLES, F.L. \& MANHEIM, F.T. (1975) Interstitial solutions and diagenesis in deeply buried marine sediments; results from the Deep Sea Drilling Project. Geochim. Cosmochim. Acta. 30, 103-127.

SCHLANGer, S.O. \& Douglas, R.G. (1974) The pelagic oozechalk-limestone transition and its implications for marine stratigraphy. In : Pelagic Sediments: on Land and under the Sea (Ed. by K. J. Hsü and H. C. Jenkyns), Spec. Publs int. Ass. Sediment. 1, 117-148. Blackwell Scientific Publications, Oxford.

SCHolle, P.A. (1977) Chalk diagenesis and its relation to petroleum exploration: Oil from chalk, a modern miracle? Bull. Am. Ass. Petrol Geol. 61, 982-1009.

SCHOLle, P.A. (1977) Chalk diagenesis and its relation to petroleum exploration: Oil from chalk, a modern miracle? Bull. Am. Ass, Petrol Geol. 61, 982-1009.

Shackleton, N.J. \& KennetT, J.P. (1975) Paleotemperature history of the Cenozoic and the initiation of the Antarctic glaciation: oxygen and carbon isotope analyses in DSDP Sites 277, 279, and 281. Init. Rep. Deep Sea drill. Proj. 29, 743-755.

SOMmer, S.E. (1972) Cathodoluminescence of carbonates, 1. Characterization of cathodoluminescence from carbonate solid solution. Chem. Geol. 9, 257-273.

TOURTELOT, H.A.\& RyE, R.O. (1969) Distribution of oxygen and carbon isotopes in fossils of Late Cretaceous age, western interior of North America. Bull.geol. Soc. Am. 80, $1903-1922$

WANLESS, H.R. (1979) Limestone response to stress: pressure solution and dolomitization. J. sedim. Petrol. 49, 437-462.

Young, K. (1963) Mesozoic history, Llano region. In: Field Excursion-Geology of Llano Region and Austin area. Guidebook No. 5, pp. 98-106 (V.E. Barnes et al.). Bureau of Economic Geology.

Young, K., Barker, D.S. \& JoNAS, E.C. (1975) Stratigraphy of the Austin Chalk in the vicinity of Pilot Knob. South Central Section G.S.A. 9th Annual Meeting, Field Trip Guide Book. 